\title{
PENERAPAN METODE SIMPLE ADDITIVE WEIGHT (SAW) PADA APLIKASI PENENTUAN PILOT PADA RUTE PENERBANGAN
}

\author{
Ria Angdra Triwulandari Damping 1), Addy Suyatno ${ }^{2)}$, Dyna Marisa Khairina ${ }^{3)}$ \\ ${ }^{1,2,3)}$ Program Studi Ilmu Komputer,Fakultas Ilmu Komputer dan Teknologi Informasi Universitas Mulawarman \\ Alamat Jl. Panajam Kampus Gunung Kelua Universitas Mulawarman Samarinda \\ Email : riaangdra@gmail.com ${ }^{1)}$, addysuyatno@yahoo.com ${ }^{2)}$,dyna.ilkom@gmail.com ${ }^{3)}$
}

\begin{abstract}
ABSTRAK
Perkembangan industri transportasi saat ini sudah sangat berkembang karena kecepatan dan pelayanan yang sangat baik membuat transportasi udara makin digemari. Hal tersebut juga sangat mempengaruhi jam kerja awak pesawat terutama pilot yang akan mengalami peningkatan jam kerja sesuai dengan banyaknya jumlah penerbangan yang harus dilayani. Penjadwalan jam kerja seorang pilot tidak dapat diserahkan kepada sembarang pihak dan tentunya telah diatur oleh pihak profesional. Sistem pendukung keputusan merupakan satu dari berbagai solusi pada kasus ini. Penerapan metode Simple Additive Weight (SAW) pada aplikasi penentuan pilot pada rute penerbangan selanjutnya. Dengan menggunakan aturan penerbangan, dan kebutuhan maskapai penerbangan yaitu: batas jam terbang dalam 24 jam, 1 minggu, 1 bulan, 1 tahun, dan batas jam kerja pilot dalam 1 hari yang kemudian akan dijadikan indikator pada metode SAW. Bobot merupakan input pengguna aplikasi sesuai dengan tingkat kepentingan maskapai penerbangan. Data pilot, dan data penerbangan pada aplikasi ini disediakan oleh pengguna aplikasi. Sistem akan melakukan pencarian untuk penerbangan yang belum memiliki data pilot. Sistem memberikan output akhir berupa jadwal penerbangan yang dapat di ekspor dalam bentuk ekstensi pdf sebagai bentuk laporan untuk penerbang.
\end{abstract}

Kata kunci: Sistem Pendukung Keputusan, Metode Penjumlahan Terbobot, Penerbangan, Pilot, Jadwal

\section{PENDAHULUAN}

Perkembangan industri transportasi saat ini sudah sangat berkembang dengan beraneka ragam jenis angkutannya, meliputi angkutan darat, angkutan laut, dan angkutan udara. Industri transportasi yang mengalami perkembangan sangat pesat adalah angkutan udara. Karena kecepatan dan pelayanan yang sangat baik membuat transportasi udara makin digemari.

Menurut Badan Pusat Statistik (Berita Resmi Statistik No. 12/02/Th. 17, 1 Februari 2017) jumlah penumpang udara di sejumlah Bandara di Indonesia pada bulan desember tahun 2016 mencapai 78 juta orang. Angka ini naik 16,8 persen dari bulan november 2016. Hampir pada seluruh bandar udara di kota-kota besar mengalami peningkatan[1]. Hal ini tentunya menjadi subjek yang menarik perhatian dalam peningkatan pelayanan baik dalam segi keamanan maupun kenyamanan maskapai penerbangan.

Hal tersebut juga sangat mempengaruhi jam kerja awak pesawat terutama pilot yang akan mengalami peningkatan flight duty atau jam kerja sesuai dengan banyaknya jumlah penerbangan yang harus dilayani. Penjadwalan jam kerja seorang pilot tidak dapat diserahkan kepada sembarang pihak dan tentunya telah diatur oleh pihak profesional.

Berlandaskan oleh peraturan ketat yang telah diterapkan oleh peraturan penerbangan atau Civil Aviation Safety Regulations (CASR) di Indonesia, memastikan pilot tidak akan mengalami kelelahan dalam penerbangan (Flight Fatigue) yang dapat berakibat fatal. Namun karena adanya peraturan
CASR 121 Amendment 10 (Lampiran Peraturan Menteri Perhubungan PM. 107 Tahun 2015), menetapkan jadwal kerja untuk seorang pilot terkadang menjadi sangat rumit dan membutuhkan waktu yang cukup lama [2]. Hal ini tidak sesuai dengan kebuhan maskapai penerbangan yang harus tepat waktu dan memiliki jadwal yang padat. Hal ini menyebabkan maskapai penerbangan mengeluarkan biaya lebih untuk memperkerjakan lebih banyak kru untuk penjadwalan atau scheduling crew ketika memiliki penerbangan yang lebih padat.

Dengan adanya sistem pendukung keputusan seharusnya masalah ini dapat dipecahkan. Salah satu metode yang sesuai untuk masalah ini adalah Simple Additive Weighting. Metode SAW dipilih karena sangat sederhana, mudah di-implementasikan, dan menggunakan konsep pembobotan dalam perhitungannya. Pembobotan ini akan memudahkan scheduling crew untuk menentukan tingkat kepentingan dari setiap indikator yang dimiliki.

Setelah memperhatikan faktor-faktor kebutuhan yang dimiliki oleh maskapai penerbangan ini, maka dibangunlah sebuah aplikasi yang dapat menyelesaikan masalah ini menggunakan sistem pendukung keputusan. Oleh karena itu, penulis mengajukan sebuah penelitian berjudulkan "Penerapan Metode SAW Pada Aplikasi Penentuan Pilot Pada Rute Selanjutnya”.

\section{TINJAUAN PUSTAKA}

A. Sistem Pendukung Keputusan

Sistem Pendukung Keputusan adalah suatu pendekatan (atau metodologi) untuk mendukung 
pengambilan keputusan yang fleksibel, interaktif dan dapat diadaptasi yang dikembangkan untuk mendukung solusi untuk masalah manajemen spesifik yang tidak terstruktur, menggunakan data, memberikan antarmuka pengguna yang mudah dan dapat menggabungkan pemikiran pengambil keputusan. Konsep Sistem Pendukung Keputusan (SPK) / Decision Support Sistem (DSS) pertama kali diungkapkan pada awal tahun 1970-an oleh Michael S. Scott Morton dengan istilah Management Decision Sistem. Sistem penunjang keputusan merupakan sistem berbasis komputer yang diharapkan dapat membantu menyelesaikan masalah-masalah yang komplek yang tidak terstruktur maupun yang semi terstruktur. Sistem Penunjang Keputusan merupakan perpaduan antara keahlian manusia dan juga komputer. Dengan kemampuan yang dimiliki, sistem penunjang keputusan diharapkan dapat membantu dalam pengambilan keputusan baik untuk masalah semi terstruktur maupun tidak terstruktur[3].

\section{B. Simple Additive Weighting (SAW)}

Metode Simple Additive Weighting (SAW) sering juga dikenal istilah metode penjumlahan terbobot. Konsep dasar metode SAW adalah mencari penjumlahan terbobot dari rating kinerja pada setiap alternatif pada semua atribut (Fishburn, 1967) (MacCrimmon, 1968). Metode SAW membutuhkan proses normalisasi matriks keputusan (X) ke suatu skala yang dapat diperbandingkan dengan semua rating alternatif yang ada. Metode SAW ini mengharuskan pembuat keputusan menentukan bobot bagi setiap atribut. Skor total untuk alternatif diperoleh dengan menjumlahkan seluruh hasil perkalian antara rating (yang dapat dibandingkan lintas atribut) dan bobot tiap atribut. Rating tiap atribut haruslah bebas dimensi dalam arti telah melewati proses normalisasi matriks sebelumnya [4].

\section{Jam Kerja Pilot}

Organisasi penerbangan sipil internasional atau International Civil Aviation Organization (ICAO) merupakan organisasi penerbangan di bawah naungan Perserikatan Bangsa-Bangsa (PBB) yang dibentuk melalui Konvensi Chicago pada Desember 1944 yang dihadiri oleh 52 negara. Tujuannya untuk menjamin keselamatan penerbangan dan pengembangan angkutan udara internasional. Organisasi ini beranggotakan 190 negara, termasuk Indonesia. ICAO menerbitkan Annex 1 sampai Annex 18 yang disebut Standards and Recommended Practices (SARPs) sebagai pedoman untuk menyusun peraturan keselamatan dan keamanan di negara masing-masing.

Indonesia memberlakukan peraturan keselamatan dan keamanan penerbangan sipil diterbitkan oleh Menteri Perhubungan sekaligus Direktur Jenderal Perhubungan Udara RI yang dikenal sebagai Civil Aviation Safety Regulations (CASR) atau dalam Bahasa Indonesia disebut Peraturan Keselamatan Penerbangan Sipil (PKPS).
CASR sendiri mengacu pada Federal Aviation Regulations (FAR) buatan Federal Aviation Authority (FAA) Amerika Serikat. CASR-CASR tersebut direvisi dan dimutakhirkan secara berkala sesuai dengan perubahan yang ada pada ICAO Annex maupun perkembangan industri penerbangan [6].

\section{Java}

JAVA adalah bahasa multiplatform atau dapat berjalan di hampir semua platform dan banyak digunakan pada komputer ataupun perangkat Handphone dan Device lainnya seperti Android. Aplikasi Java diciptakan dengan file teks berekstensi. Java program ini dikompilasi menghasilkan satu berkas bytecode berekstensi class atau lebih. Bytecode adalah serangkaian instruksi serupa instruksi kode mesin. Perbedaannya adalah kode mesin harus dijalankan pada sistem komputer dimana kompilasi ditujukan, sementara bytecode berjalan pada java interpreter yang tersedia di semua platform sistem komputer dan sistem operasi.

\section{HASIL DAN PEMBAHASAN}

\section{A. Deskripsi Sistem}

Aplikasi penentuan pilot pada rute penerbangan selanjutnya dapat melakukan penentuan pilot yang sesuai dengan peraturan penerbangan dengan menerapkan metode Simple Additive Weighting. Dalam metode ini, admin akan memberikan data penerbangan selanjutnya. Sistem akan melakukan perhitungan dengan metode Simple Additive Weighting untuk mendapatkan pilot yang tepat untuk penerbangan selanjutnya. Sistem akan mengisi nilai indikator yang telah ditentukan sesuai dengan peraturan penerbangan dari data penerbangan sebelumnya. Setelah pilot untuk penerbangan berikutnya didapatkan oleh sistem, kemudian admin dan user dapat melihat output aplikasi berupa jadwal penerbangan terbaru. Jadwal penerbangan yang diberikan sistem ini akan menjadi informasi untuk pilot maupun staff maskapai penerbangan.

Untuk mendukung pembuatan aplikasi ini, data pilot, dan data penerbangan didapatkan dari crew scheduling maskapai penerbangan. Sehingga sistem ini dapat bekerja layaknya sebuah sistem yang telah di-implementasi secara nyata.

\section{B. Perancangan Sistem}

Perancangan analisis sistem penerapan metode SAW pada aplikasi penentuan pilot ini menggunakan Unified Modeling Language (UML). UML yang digunakan adalah Class Diagram, Sequence Diagram, dan Activity Diagram. 


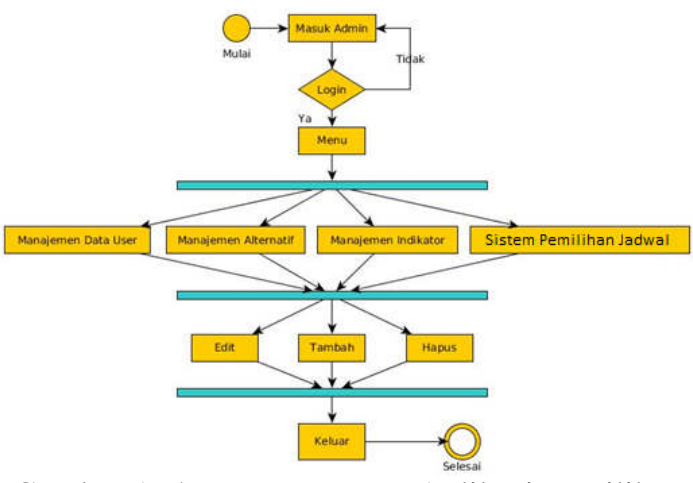

Gambar 1. Activity Diagram Aplikasi Pemilihan Pilot untuk Penerbangan Selanjutnya

Pada Gambar 1 Activity Diagram Aplikasi Pemilihan Pilot untuk Penerbangan Selanjutnya ditunjukan bahwa seorang admin sistem pendukung keputusan dapat melakukan login kedalam sistem untuk mengolah data sistem seperti data user (menambah dan menghapus), Pilot / Alternatif (Menghapus, mengedit, dan menambah), Indikator (menambah, menghapus, mengubah), dan melakukan penilaian/pemilihan jadwal pilot.

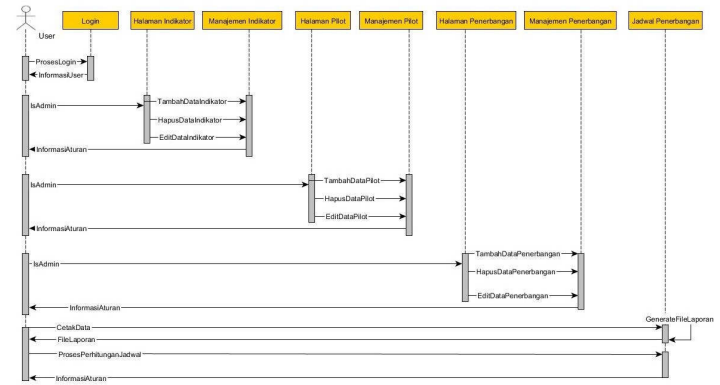

Gambar 2. Sequence Diagram Aplikasi Pemilihan Pilot untuk Penerbangan Selanjutnya

Pada Gambar 2 Sequence Diagram Aplikasi Pemilihan Pilot untuk Penerbangan Selanjutnya ditunjukan bahwa admin melakukan login untuk dapat mengakses manajemen user, manajemen pilot, dan manajemen penerbangan. Pada Manajemen Data Pilot admin dapat melihat data pilot kemudian juga menambah, menghapus, dan mengubah data pilot. Pada Manajemen Data User admin dapat melihat informasi data admin dan menghapus atau mengubah data admin. Pada halaman jadwal, user dapat memproses jadwal penerbangan sehingga sistem akan mencari pilot yang tepat untuk penerbangan selanjutnya.

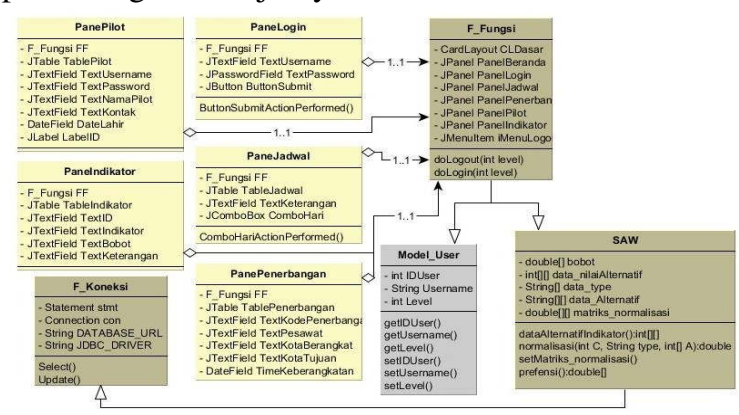

Gambar 3. Class Diagram Aplikasi Pemilihan Pilot untuk Penerbangan Selanjutnya
Pada Gambar 3 Class Diagram Aplikasi Pemilihan Pilot untuk Penerbangan Selanjutnya ditunjukan bahwa terdapat class Fungsi yang merupakan parent dari hampir seluruh class lain. Hal ini terjadi agar sistem tidak perlu membuat koneksi baru untuk satu lingkungan atau pengguna aplikasi. Setiap class panel memiliki relasi dengan class Fungsi berupa one-to-one, yang berarti setiap class panel hanya memiliki satu jenis class untuk dipanggil berulang kali.

\section{Perancangan Database}

Struktur tabel yang digunakan dalam pembuatan program ini dapat dilihat pada tabel-tabel ini :

\section{Tabel Data User}

Digunakan sebagai tempat penyimpanan datadata admin dalam aplikasi. Struktur tabel data user ditunjukan pada Tabel 1 Struktur Tabel Data Admin. Tabel 1 Struktur Tabel Data Admin

\begin{tabular}{|c|c|c|}
\hline Field Name & Data Type & Field Size \\
\hline ID & Int & 11 \\
\hline Username & Varchar & 55 \\
\hline Nama & Varchar & 75 \\
\hline Tanggallahir & Varchar & 55 \\
\hline Alamat & Varchar & 75 \\
\hline Kontak & Varchar & 55 \\
\hline Password & Varchar & 75 \\
\hline Level & Int & 11 \\
\hline
\end{tabular}

\section{Tabel Pilot}

Digunakan untuk menyimpan data-data mengenai pilot. Tabel 2 Struktur Tabel Data Pilot

Tabel 2 Struktur Tabel Data Pilot

\begin{tabular}{|c|c|c|}
\hline Field Name & Data Type & Field Size \\
\hline kol_idpilot & int & 11 \\
\hline kol_nama & Varchar & 55 \\
\hline kol_lokasi & Varchar & 55 \\
\hline kol_kontak & Varchar & 35 \\
\hline
\end{tabular}

3. Tabel Penerbangan

Digunakan untuk menyimpan data-data mengenai penerbangan.

Tabel 3 Struktur Tabel Penerbangan

\begin{tabular}{|l|c|c|}
\hline \multicolumn{1}{|c|}{ Field Name } & Data Type & Field Size \\
\hline kol_idpenerbangan & Int & 11 \\
\hline kol_penerbangan & Varchar & 55 \\
\hline kol_asal & Varchar & 20 \\
\hline kol_tujuan & Varchar & 20 \\
\hline kol_hari & Varchar & 55 \\
\hline kol_pesawat & Varchar & 30 \\
\hline kol_durasi & Float & 10 \\
\hline kol_pilot & Varchar & 55 \\
\hline
\end{tabular}


4. Tabel Indikator dan Bobot

Digunakan untuk menyimpan data-data mengenai Indikator dan Bobot.

Tabel 4 Struktur Tabel Indikator Bobot

\begin{tabular}{|c|c|c|}
\hline Field Name & Data Type & Field Size \\
\hline kol_idindikator & Int & 11 \\
\hline kol_namaindikator & Varchar & 55 \\
\hline kol_keterangan & Varchar & 75 \\
\hline kol_bobot & Float & 10 \\
\hline kol_type & Varchar & 55 \\
\hline
\end{tabular}

\section{Implementasi dan Pengujian Sistem}

\section{Halaman Login}

Halaman Login adalah halaman utama yang pertama kali tampil ketika pengunjung mengakses aplikasi. Halaman ini adalah halaman depan ketika pengguna aplikasi belum dan akan melakukan proses login. Pada halaman ini diberikan form login dengan input username dan password. Setelah pengguna aplikasi memberikan username dan passwordnya, pengguna aplikasi dapat menekan tombol login untuk memulai proses login. Pengguna aplikasi akan dapat mengakses beberapa menu seperti menu manajemen user, menu manajemen indikator dan bobot, menu manajemen pilot, dan menu manajemen penerbangan. Halaman Login dapat dilihat dari Gambar 4.

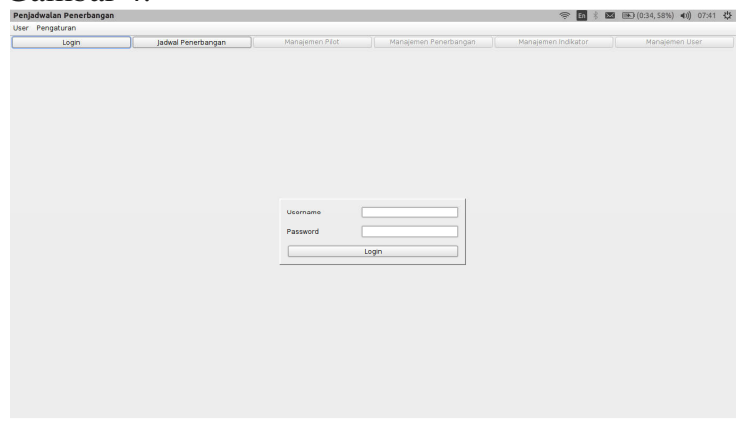

Gambar 4. Halaman Login

\section{Halaman Manajemen User}

Halaman Manajemen User adalah halaman dimana pengguna dapat melihat, menambah, mengubah, dan menghapus data pengguna aplikasi yang terdaftar agar dapat mengakses menu majamen pilot dan manajemen penerbangan. Untuk menambah data user, pengguna aplikasi memberikan data username, nama, tanggal lahir, kontak, alamat, dan password user baru. Kemudian pengguna dapat menekan tombol tambah untuk memproses tambah data sesuai dengan yang telah diberikan sebelumnya. Untuk mengubah data yang telah ada, user dapat memilih data yang akan diubah pada tabel data user. Kemudian data user akan ditampilkan pada form user. Kemudian pengguna aplikasi dapat mengubah data yang akan diubah dalam form user tersebut sesuai dengan kebutuhan pengguna aplikasi. Setelah data baru diberikan pada form user, pengguna aplikasi menekan tombol ubah untuk menerapkan perubahan yang telah dilakukan. Tabel akan menampilkan data terbaru yang tersimpan. Pada halaman ini juga pengguna dapat menghapus data user yang telah ada. Pengguna dapat menghapus data user dengan memilih data yang akan dihapus pada tabel user, kemudian pengguna aplikasi menekan tombol hapus untuk menghapus data user yang telah ditentukan sebelumnya. Halaman user dapat dilihat pada Gambar 5 .

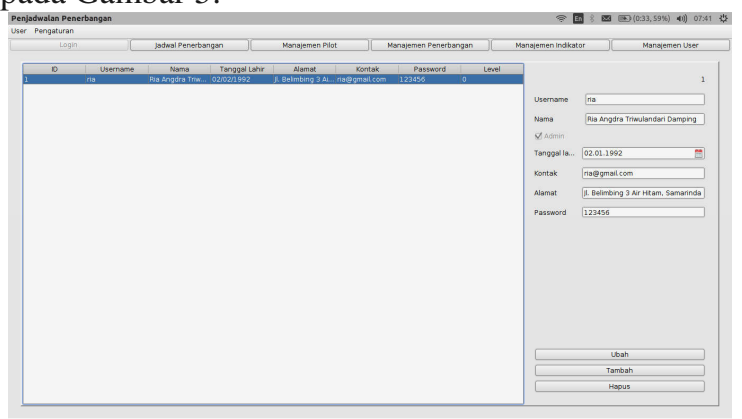

Gambar 5. Halaman Manajemen User

\section{Halaman Manajemen Pilot}

Halaman Manajemen Pilot adalah halaman dimana pengguna dapat melihat, menambah, mengubah, dan menghapus data pilot yang terdaftar agar dapat menjadi alternatif pilihan pada saat penentuan pilot pada sebuah penerbangan. Untuk menambah data pilot, pengguna aplikasi memberikan data nama pilot, lokasi pilot, dan kontak pilot yang baru. Kemudian pengguna dapat menekan tombol tambah untuk memproses tambah data sesuai dengan yang telah diberikan sebelumnya. Untuk mengubah data yang telah ada, pengguna aplikasi dapat memilih data yang akan diubah pada tabel data pilot. Kemudian data pilot akan ditampilkan pada form pilot.

Selanjutnya pengguna aplikasi dapat mengubah data yang akan diubah dalam form pilot tersebut sesuai dengan kebutuhan pengguna aplikasi. Setelah data baru diberikan pada form pilot, pengguna aplikasi menekan tombol ubah untuk menerapkan perubahan yang telah dilakukan. Tabel akan menampilkan data terbaru yang tersimpan. Pada halaman ini juga pengguna dapat menghapus data pilot yang telah ada. Pengguna dapat menghapus data pilot dengan memilih data yang akan dihapus pada tabel pilot, kemudian pengguna aplikasi menekan tombol hapus untuk menghapus data pilot yang telah ditentukan sebelumnya. Halaman Manajemen Pilot dapat dilihat pada Gambar 6.

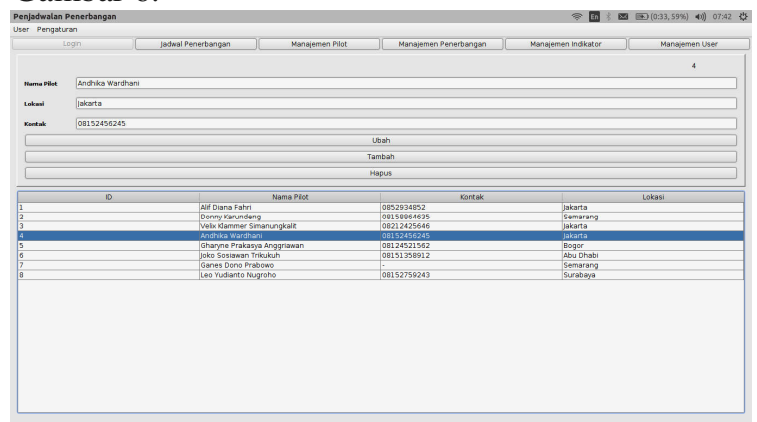

Gambar 6. Halaman Manajemen Pilot 


\section{Halaman Manajemen Indikator dan Bobot}

Halaman ini dapat diakses oleh admin dan pada halaman ini admin dapat melihat, mengubah, menambahkan, atau menghapus data indikator dan bobot yang akan digunakan dalam perhitungan dengan metode SAW. Untuk menambah data indikator, pengguna aplikasi memberikan data nama indikator, nilai bobot, tipe indikator, dan keterangan yang baru. Kemudian pengguna dapat menekan tombol tambah untuk memproses tambah data sesuai dengan yang telah diberikan sebelumnya. Untuk mengubah data yang telah ada, pengguna aplikasi dapat memilih data yang akan diubah pada tabel data indikator. Kemudian data indikator akan ditampilkan pada form indikator. Selanjutnya pengguna aplikasi dapat mengubah data yang akan diubah dalam form indikator tersebut sesuai dengan kebutuhan pengguna aplikasi. Setelah data baru diberikan pada form indikator, pengguna aplikasi menekan tombol ubah untuk menerapkan perubahan yang telah dilakukan. Tabel akan menampilkan data terbaru yang tersimpan. Pada halaman ini juga pengguna dapat menghapus data indikator yang telah ada. Pengguna dapat menghapus data indikator dengan memilih data yang akan dihapus pada tabel indikator, kemudian pengguna aplikasi menekan tombol hapus untuk menghapus data indikator yang telah ditentukan sebelumnya. Halaman manajemen Indikator dan Bobot dapat dilihat pada Gambar 7.

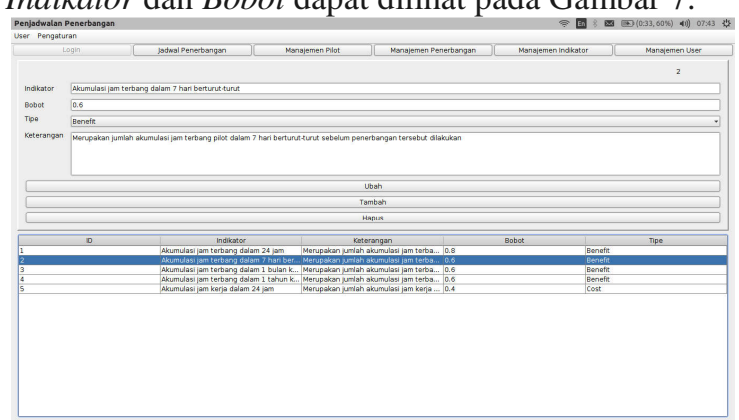

Gambar 7. Halaman Indikator dan Bobot

\section{Halaman Manajemen Penerbangan}

Halaman ini dapat diakses oleh admin dan pada halaman ini admin dapat melihat, mengubah, menambahkan, atau menghapus data penerbangan yang akan disimpan maupun dicari secara otomatis oleh sistem pilot yang tepat untuk penerbangan tersebut. Untuk menambah data penerbangan, pengguna aplikasi memberikan data nama penerbangan, asal, tujuan, tanggal, waktu, jenis pesawat yang baru. Namun pengguna aplikasi juga dapat secara manual menambahkan pilot untuk penerbangan tersebut dengan mengisi form pilot. Sistem akan melakukan pencarian keputusan pilot terbaik untuk penerbangan yang belum ditentukan pilotnya. Kemudian pengguna dapat menekan tombol tambah untuk memproses tambah data sesuai dengan yang telah diberikan sebelumnya. Untuk mengubah data yang telah ada, pengguna aplikasi dapat memilih data yang akan diubah pada tabel data penerbangan. Kemudian data penerbangan akan ditampilkan pada form penerbangan. Selanjutnya pengguna aplikasi dapat mengubah data yang akan diubah dalam form penerbangan tersebut sesuai dengan kebutuhan pengguna aplikasi. Setelah data baru diberikan pada form penerbangan, pengguna aplikasi menekan tombol ubah untuk menerapkan perubahan yang telah dilakukan. Tabel akan menampilkan data terbaru yang tersimpan. Pada halaman ini juga pengguna dapat menghapus data penerbangan yang telah ada. Pengguna dapat menghapus data penerbangan dengan memilih data yang akan dihapus pada tabel penerbangan, kemudian pengguna aplikasi menekan tombol hapus untuk menghapus data penerbangan yang telah ditentukan sebelumnya. Halaman Manajemen Penerbangan dapat dilihat pada Gambar 8 .

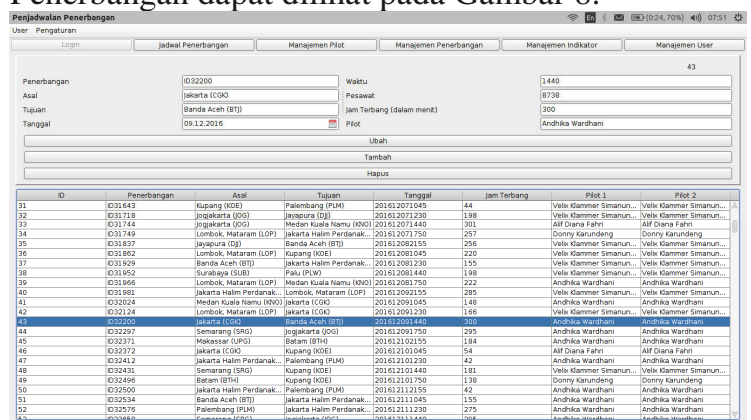

Gambar 8. Halaman Manajemen Penerbangan

\section{Halaman Jadwal Penerbangan dan Kerja Pilot}

Halaman ini dapat diakses oleh seluruh pengguna aplikasi tanpa perlu melakukan login. Pada saat pertama kali halaman ini dibuka, pengguna aplikasi akan melihat data jadwal penerbangan untuk hari ini. Ketika pengguna aplikasi ingin melihat jadwal penerbangan untuk hari yang lainnnya, pengguna aplikasi dapat memilih tanggal pada form tanggal di atas tabel dan kemudian menekan tombol proses jadwal. Kemudian sistem akan menampilkan data jadwal penerbangan pada tanggal yang dipilih dalam tabel jadwal penerbangan. Tombol proses jadwal ini juga berfungsi untuk memeriksa data penerbangan jika ada yang belum ditentukan pilotnya. Jika ternyata sistem mendapati penerbangan yang belum ditentukan pilotnya, sistem akan melakukan pencarian pilot yang terbaik untuk penerbangan tersebut dan jika ada maka juga semua penerbangan setelah penerbangan yang belum ditentukan tersebut. Pengguna aplikasi juga dapat mencetak laporan berupa jadwal penerbangan untuk pilot dengan memilih nama pilot lalu menekan tombol cetak laporan di bagian bawah tabel. Halaman Jadwal Penerbangan dan Kerja Pilot dapat dilihat pada Gambar 9. 


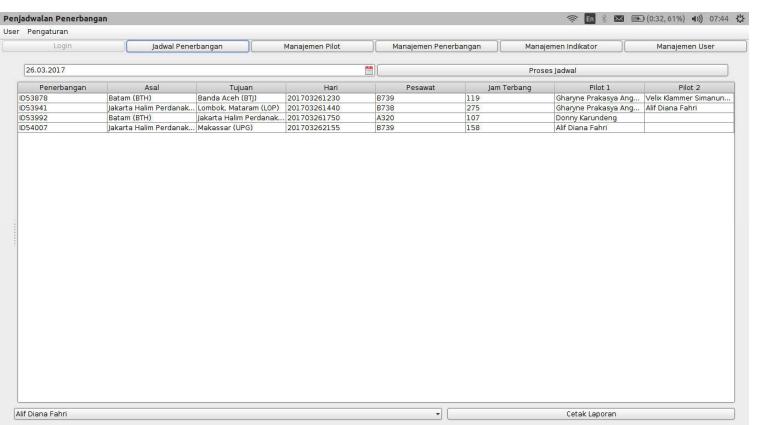

Gambar 9. Halaman Jadwal Penerbangan dan Kerja Pilot

Setelah tombol Cetak Laporan ditekan oleh pengguna aplikasi, maka aplikasi akan menampilkan pesan mengenai status eksport dokumen dan lokasi dokumen tersebut di eksport. Kemudian aplikasi juga akan membuka hasil eksport dengan format pdf seperti pada Gambar 10.

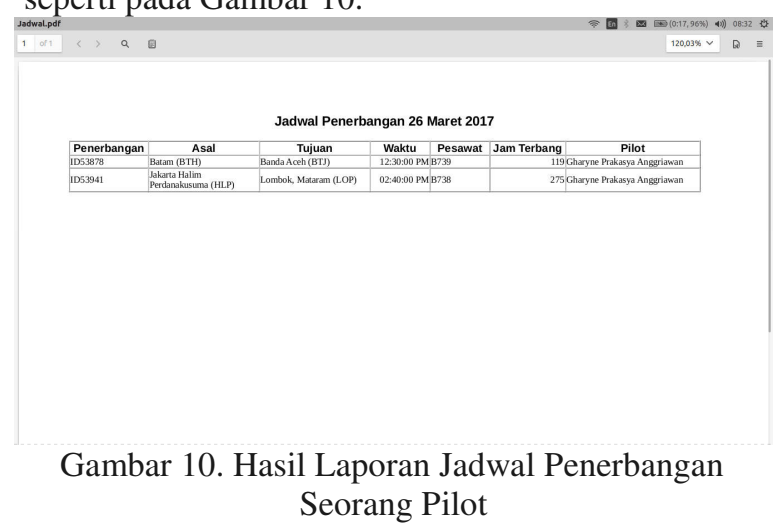

\section{KESIMPULAN DAN SARAN}

Berdasarkan hasil penelitian mengenai penerapan metode simple additive weight (SAW) pada aplikasi penentuan pilot pada rute penerbangan selanjutnya, dapat diambil kesimpulan:

1. Aplikasi penentuan pilot pada rute penerbangan selanjutnya dibangun dengan menggunakan metode Simple Additive Weighting (SAW).

2. Sistem pakar ini bekerja berdasarkan data riwayat penerbangan pilot dan data penerbangan yang akan dilakukan untuk dilakukan perhitungan menggunakan metode Simple Additive Weighting dengan input bobot oleh user.

3. Berdasarkan pengujian yang dilakukan oleh pakar, tingkat keakurat aplikasi sebesar 100\%.

\section{SARAN}

Adapun saran yang dapat diberikan penulis untuk pengembangan sistem ini kedepannya antara lain:

1. Sistem ini terbatas hanya untuk satu maskapai penerbangan. Sehingga dapat dikembangkan untuk beberapa maskapai penerbangan ataupun ruang lingkup yang lebih luas.

2. Sistem pakar ini dapat dikembangkan dengan metode lainnya dan dapat dijadikan model pengembangan sistem yang lebih baik.

3. Penulis lain diharapkan dapat mengembangkan aplikasi yang telah dibuat ini dan dapat menambahkan ide-ide yang lebih menarik serta interface yang lebih baik lagi.

\section{DAFTAR PUSTAKA}

[1] Badan Pusat Statistik. 2017. Perkembangan Transportasi Nasional Desember 2016 [pdf]. dalam https://www.bps.go.id/website/brs_ind/brsInd20170201113419.pdf [diakses pada 20 Februari 2017]

[2] Kementrian Perhubungan. 2016. CASR Part 121 Amdt. 10 - Certification and Operating Requirements Domestic, Flag and Supplemental Air Carrier [pdf], dalam: http://hubud.dephub.go.id/?id/dsku/download/6 684 [diakses pada 4 April 2016]

[3] Khoiruddin, M. 2011. Sistem Pendukung Keputusan Analisis Kepribadian Menurut Hippocrates dengan Menggunakan Metode AHP dan Profile Matching. Skripsi. Universitas Sumatera Utara.

[4] Kusumadewi, Sri. 2003. Artificial Intelligence (Teknik dan Aplikasinya). Jakarta : Graha Ilmu.

[5] ICAO. t.t. About ICAO, [online] dalam: http://www.icao.int/abouticao/Pages/default.aspx [Diakses pada 24 November 2015]. 